\section{Comparative analysis of historic predictions
and actual global natural gas market trends \\ Comparative analysis of historic predictions
and actual global natural gas market trends for the period from 1997 to 2020}

Rudarsko-geološko-naftni zbornik

(The Mining-Geology-Petroleum Engineering Bulletin) UDC: 62

DOI: 10.17794/rgn.2021.4.14

Review scientific paper

\author{
Domagoj Šamarinec'; Daria Karasalihović Sedlar'; Ivan Smajla'; Lucija Jukić' \\ ${ }^{1}$ University of Zagreb, Faculty of Mining, Geology and Petroleum Engineering, Pierottijeva 6, 10000 Zagreb
}

\begin{abstract}
An accurate prediction of energy indicators is critical for orientation in the energy market, and it could give direction for policymakers and market participants. The aim of this research was to examine the accuracy of projections of natural gas market indicators. This paper presents a comparative analysis of historic predictions and actual global natural gas movements in several segments, namely production, consumption, and regional import dependence, as well as forecasted and actual price movements. The goal of this paper is to compare projected and actual natural gas market indicators. Predictions of market movements 20 years into the future are very useful, but they do have certain limitations. Those limitations especially apply to goods whose prices are regional and linked to price movements of another good, as is the case with natural gas. External influences have a direct impact on production and consumption, and it is rather clear that changes in one of the fundamental factors entails and magnifies the error of further predictions. Despite that, predictions of global production and consumption have proven to be very accurate. Based on the research results, it could be emphasized that for strategical planning and policy-making purposes, the predictions of natural gas production, consumption, or even import independence could be considered with great certainty, while price assumptions in the case of natural gas have shown significant mismatching, therefore, should be very carefully perceived.
\end{abstract}

\title{
Keywords:
}

natural gas production; natural gas consumption; gas market prediction; energy market trends

\section{Introduction}

As a response to the growing awareness of the world population about the effects of fossil fuels on climate change and calls from experts and activists for a reduction in greenhouse gas emissions (Akdag and Yıldırım, 2020), natural gas has become a transitional fuel during the shift of humanity from other, more polluting fossil fuels towards renewable energy (Smajla et al., 2020; Gürsan and de Gooyert, 2021). The effect of that is a steady increase in natural gas shares in global energy consumption and gains in its strategic importance (Scharf et al., 2021) as natural gas gradually replaces coal and oil as primary fossil fuels (Paraschiv and Paraschiv, 2020). Due to European emission restrictions, mainly from coal-fired power plants, many member states have started to replace coal-fired power plants, with cleaner gas-fired power plants (Wynn and Coghe, 2017; Bayer and Aklin, 2020). Projections and predictions are a very important segment of the economy in optimizing production (Ikpeka et al., 2019; al Irsyad et al, 2019), a well-timed response to market demand (Strpić et al., 2017), optimal inventory management

Corresponding author: Ivan Smajla

ivan.smajla@rgn.hr and price regulation ( $\mathbf{L u}$ et al., 2021). The accurate prediction of energy trends and prices is critical for orientation in the energy market, and it could give direction for policymakers and market participants. The significance of forecasting has three aspects, which include: the possibility of dynamical cost control; accurate predictions of the market trends and market opportunities, and a scientific basis for policy formulation and market regulation (Lu et al., 2021). Price fluctuations affect the energy flows and distribution of hydrocarbon resources in the energy market and have substantial economic leverage (Kaufmann and Connelly, 2020). Some of the main factors that are considered during forecasting include supply and demand, market participants, costs, energy system structure, and socio-economic framework (Nowotarski and Weron, 2018). In order for predictions to be confirmed, it is necessary to analyse the predictions after a certain period so that future predictions can be made with greater accuracy, especially energy price predictions which are affected by different external factors. Over the past decade, publications on energy price forecasts have shown an overall upward trend, especially after 2017 (Lu et al., 2021). The prediction horizon of natural gas and oil prices are mostly short-term and medium-term and only a few studies are long-term, therefore there is a bigger inaccuracy (Lu et al., 2021). This 
Table 1: Regions formed and used in World Energy Model for regional and global predictions

\begin{tabular}{|l|l|}
\hline Region & \\
\hline OECD Europe & $\begin{array}{l}\text { United Kingdom, France, Germany, Italy, Spain, Finland, Poland, Czechia, Hungary, Austria, } \\
\text { Greece, Turkey, and other Western European countries }\end{array}$ \\
\hline Africa & Egypt, Algeria, Libya, Nigeria, South Africa, and other African countries \\
\hline Middle East & Iran, Iraq, Saudi Arabia, UAE, Kuwait, Qatar, Israel, and other Middle Eastern countries \\
\hline North America & the United States of America and Canada \\
\hline Latin America & Mexico, Brazil, Argentina, Venezuela, Caribbean countries, and other South American countries \\
\hline Asia & $\begin{array}{l}\text { China, East Asia (of which: Indonesia, Mongolia, Afghanistan, Vietnam, and other Eastern Asian } \\
\text { countries), South Asia (of which: India, Pakistan, and Bangladesh) }\end{array}$ \\
\hline Transition economies & $\begin{array}{l}\text { Russia, Ukraine, Belarus, Armenia, Azerbaijan, Estonia, Georgia, Kazakhstan, Kyrgyzstan, Latvia, } \\
\text { Lithuania, Moldova, Tajikistan, Turkmenistan, Uzbekistan, Croatia, Slovenia, Serbia, Bosnia and } \\
\text { Herzegovina, North Macedonia, Montenegro, Kosovo, Slovakia, Bulgaria, and Romania }\end{array}$ \\
\hline OECD Pacific & Australia, Japan, and New Zealand \\
\hline
\end{tabular}

paper gives a comparative analysis of historic predictions and actual global natural gas trends in several segments, namely production, consumption and regional import dependence, as well as assumed and actual price movements. Since predictions are inherently uncertain, the goal of this paper is to determine and present deviations of past historic predictions from actual values. Important factors, which cannot be expressed with mathematical equations, are various unforeseen climate changes, as well as financial (economic) and political decisions that can have a significant impact on production and consumption but cannot possibly be predicted. Such factors would include earthquakes, floods, seasonal temperature extremes, or wars. The term "natural gas" in this paper refers to a mixture of hydrocarbons in which methane predominates. This term "natural gas" is widely used and known in the oil industry and gas sector. The unit "billion cubic meters" (bcm) used in this paper refers to a volume of $1 \times 10^{9} \mathrm{~m}^{3}$ of natural gas.

\section{Projected global natural gas movements}

Projections were acquired from predictions presented in a reference scenario of World Energy Outlook 2000 (WEO), created by the International Energy Agency (IEA). Predictions were completed and published in 2000 and span the period from 1997 to 2020. The reference scenario in its predictions accounts for the implementation of all policies intended for climate stabilization, which have been enacted or announced by mid2000. The reference scenario does not account for policies which were supposed to be implemented by 2020 but have not been enacted or announced by mid2020. IEA provided long term energy predictions using a World Energy Model (WEM), a mathematical model whose main exogenous assumptions are GDP, population, international fossil fuel prices and technological developments. Predicted fossil fuel demand, including natural gas, serves as an input for supply models. Be- sides global predictions, WEM is also used for regional predictions (IEA, 2000). Regions formed and used in the World Energy Model for regional and global predictions are as follows (see Table 1).

The term "transition economies" given in Table 1 refers to countries whose economies switched from centrally planned ones to market economies.

IEA-WEO 2000 predicts the expansion of global natural gas production from 2324 billion cubic meters (bcm) in 1997 to $4315 \mathrm{bcm}$ in 2020 . Production was predicted to grow in every region, though shares of North America, Europe and transition economies in global production were to decline, primarily due to faster growth in output in Asia, Middle East and Latin America (IEA, 2000).

World natural gas consumption in a reference scenario is projected to an average annual growth of $2.7 \%$ from 1911 Mtoe in 1997 to 3551 Mtoe in 2020, or $2222 \mathrm{bcm}$ to $4130 \mathrm{bcm}$, an increase in demand of almost $86 \%$. Growth is weaker in OECD member states at $1.9 \%$, while non-OECD countries grow at 3.5\% annually. Natural gas demand in North America expands slower than any other region, while Asia experiences the strongest growth led by China, which is predicted as the most rapidly expanding region in natural gas consumption. China is followed by regions of South Asia in second and East Asia in third place regarding the demand growth rate. Despite slower demand expansion, North America, transition economies and Europe would in 2020, as in 1997, rank first, second and third respectively in total annual natural gas demand, while combined they would account for $60 \%$ of global consumption in 2020 , a decline from their share of 74\% in 1997 (IEA, 2000).

IEA predicts a doubling in imported natural gas share as part of total European gas consumption from 31\% to $62 \%$, which would be the result of projected total primary gas supply increasing faster than any other energy source. Overall European natural gas production is forecasted to remain relatively unchanged until 2020 as Norwegian production growth is expected to offset the pro- 
jected production decline in the rest of Europe, especially the United Kingdom. Considering the increase in European natural gas consumption, along with unchanged domestic production larger dependency of Europe on imports is unsurprising, with the main suppliers, Russia and Algeria, remaining unchanged but with an appearance of new ones like Liquefied Natural Gas (LNG) from Qatar, Nigeria, Trinidad \& Tobago, Egypt, Iran and Venezuela. Resources of Canada and the United States of America are expected to be largely sufficient for the projected increase in North American production resulting from technological advancement, from previously inaccessible, but major natural gas resources. The rise in demand will mostly be covered by domestic production; however, an increase in LNG imports is expected during the second half of the projection period, though volumes will be modest in relation to the total supply. The remaining demand increase could be covered by importing gas with pipelines from Mexico (IEA, 2000).

One of the main factors in the natural gas market movement predictions are price movement assumptions. Prices were postulated on the assumption that world natural gas reserves will be sufficient to support the global demand expansion. It should be noted that assumed price movements should not be interpreted as predictions and neither should smooth price trends (assumed prices in chapter 4.4) be interpreted as an expectation of stable energy markets (IEA, 2000).

\section{Actual global natural gas movements}

The following section shows the actual natural gas movements in the global market. They are analysed in the same four categories as in the previous section and are based on data made publicly available by British Petroleum (BP). Data has also been grouped into world regions with the highest possible accuracy, in order to be compatible with regions shown in IEA WEO 2000.

\subsection{Actual production up to 2018}

North America was the largest natural gas producing region in the world in 2018 and its production has been growing for quite some time, despite the recent decline in gas prices. This is mostly due to the advancement of technology, more specifically the production of shale gas using hydraulic fracturing (URL19). The American shale revolution propelled the USA to first place among the world's natural gas producers and resulted in it becoming a net exporter in 2017 for the first time in almost 60 years (URL12). The advances in technology are also visible in the fact that despite the decreasing number of oil and gas producing wells, which peaked in 2014, gas production kept growing through 2018. The most significant gas producing states in the U.S. in 2018 were Texas, Pennsylvania, Louisiana, Oklahoma and Ohio
(URL8). Alaska is also among the largest natural gas producing states, however most of the Alaskan gas is reinjected into the existing oil fields to maintain formation pressure and oil production rates. The Appalachian region is the largest gas producing region in the U.S., with its Marcellus and Utica shale formations of Ohio, West Virginia, Pennsylvania and New York (URL14). In the Marcellus shale formation in 2016, rig efficiency increased by nearly $40 \%$ in comparison to the prior year. In context, the size and growth of the Marcellus shale formation added "Canada's worth" of production to the North American natural gas market in only six years, as reported by the Canadian government. Other significant gas formations are Permian, Haynesville and Eagle Ford in Texas, the largest natural gas producing state in the U.S. In 2018, Canada was the fourth largest natural gas producer in the world behind the USA, Russia and Iran, with most of the Canadian production occurring in the Western Canadian Sedimentary Basin stretching from Manitoba to British Columbia (URL13). The aforementioned basin enabled the provinces of Alberta and British Columbia to account for almost $97 \%$ of all Canadian natural gas production in 2017 (URL4). $72 \%$ of the Canada's abundant natural gas resources are located in tight and shale gas formations of Alberta and British Columbia, with the Montney Formation, almost evenly split between Alberta and B.C., accounting for 36\% of all of Canada's natural gas resources (URL28; URL5; NEB, 2017).

OECD Europe was the 5th largest natural gas producing region in the world in 2018, a position it held since being overtaken by Asia in 2004 and a position it is at risk of losing to the Latin American region, as well as the rapidly growing Pacific region within several years. The primary cause of these developments is the almost twodecade long decline in gas production in Europe, more specifically the United Kingdom and the Netherlands (URL7). Groningen Field, in the province of the same name in north-eastern Netherlands, is the largest natural gas field in Europe. However, it has had its extraction rates capped since 2014 by the Dutch government due to seismic activity linked to gas extraction, with production cap being increasingly tightened over the years (URL27). Norway's increase in production over the past two decades made up for some of the decline in the United Kingdom and the Netherlands, but it was insufficient to completely offset the drop in production in the rest of Europe. Among the reasons for Norway's insufficient production is a rapid decline in new hydrocarbon investment in the country, as well as the fact that Norway is aiming to diversify away from oil and natural gas (URL6). One of the best examples of change in energy policy is the 2016 announcement from state-owned Equinor (previously Statoil) of a \$200 million investment in "new energy" technologies over the next four to seven years. In 2018, Norway was the largest natural gas producing country of OECD Europe, producing almost 
twice as much natural gas as the UK and the Netherlands combined, and accounting for over half of OECD Europe's gas production. After Groningen, the second largest gas field in Europe is Troll Field, located $100 \mathrm{~km}$ off the coast of Norway and containing more than half of Norway's proven natural gas reserves. Of the 5 largest offshore oil and gas fields in Europe, 4 are located in Norway with the fourth on the list, Buzzard Field, located off the coast of United Kingdom. Following Norway in order of production volumes in 2018 OECD Europe were: the United Kingdom, the Netherlands, Germany and Italy (URL2; URL23).

The combined region of Africa and the Middle East was the second largest natural gas producing region in 2018 as a result of the most rapid expansion of production over the last two decades. The most significant regional natural gas producers are Iran, Qatar, Saudi Arabia, Algeria and the United Arab Emirates. Iran is especially significant as it is the region's leading gas producer as well as being in possession of the world's second largest natural gas reserves. More specifically, in 2017, Iran accounted for $17 \%$ of the global natural gas reserves and more than one third of OPEC's reserves, owing much to its gas fields of Kish, North Pars, Golshan and South Pars in particular. The South Pars gas formation is also the reason behind Qatar's massive natural gas reserves. Qatar, as well as being the second largest producer in the region, is also ranking second in gas reserves and notably, is the largest LNG exporter in the world. Saudi Arabia, Algeria, the UAE and Nigeria, despite quite some differences in gas production output, all have rather similar natural gas reserves (URL21; URL15).

The region of transition economies is the third one in the world regarding natural gas production. By far, the largest gas producer in the region is Russia with some notable minor regional producers being Turkmenistan, Uzbekistan, Kazakhstan and Ukraine. Russia is the second largest natural gas producer in the world, just behind the U.S., and has the world's largest proven natural gas reserves, with Turkmenistan standing at number two in the region with about half the volume of Russia's proven reserves. In Russia, the most significant gas producing region is the Yamalo-Nenets Okrug which accounted for almost $80 \%$ of the country's total output in 2016. Other gas producing regions worth mentioning are KhanyMansy, Sakhalin and Orenburg representing 5\%, 5\% and $3 \%$ of Russia's gas production, respectively. YamaloNenets Okrug is also the region with most of the Russian proven gas reserves, more specifically $56 \%$ in 2016 , while the next three regions; Astrakhan, Irkutsk and Barents Sea, each accounted for about $7 \%$ of the country's natural gas reserves. Four of the five largest natural gas fields in Russia are located in the Yamalo-Nenets Okrug in Western Siberia, these being Urengoy, Yamburg, Bovanenkovo and Zapolyarnoye fields, while the fourth largest gas field in Russia, Shtokman Field, is located in the Barents Sea north-east of Murmansk (URL3). It is thus difficult to overstate the importance of Western Siberian Yamalo-Nenets Okrug in not only Russia's, but the whole region's natural gas output and energy security (BP, 2019; URL25).

In 2018, non-OECD Asia was the 4th largest gas producing region in the world. China is the leading producer, representing almost a third of all of Asia's gas production. Following China is Indonesia at less than 50\% of China's output, with Malaysia following closely behind. Other not insignificant regional producers are Thailand and Pakistan. China's gas production has experienced stunning growth since the year 2000, including production from unconventional reserves. In 2018, the collective output of all tight gas, shale gas and coalbed methane fields accounted for $41 \%$ of China's total natural gas production. This is not an accident as the Chinese government has been focusing efforts in developing tight gas from low-permeability formations since the 1970s and the EIA estimated in 2013 that there are around 32 trillion cubic meters of technically recoverable shale gas in China. Though the largest in the world, these however, are not proven reserves. Regarding proven reserves, China is again leading in the Asian region, followed by Indonesia, Malaysia, India and Myanmar.

In 2018, Latin America was the 6th largest natural gas producing region with the top five producers being Argentina, Mexico, Trinidad \& Tobago, Venezuela and Brazil. Latin American gas production growth has been levelling off for roughly a decade and the total output even experienced a decline from 2017 to 2018. This could change in the future however, if Argentina manages to develop its massive shale gas reserves in the Vaca Muerte (Dead Cow) Formation along the lines of the U.S. shale revolution. Venezuela is the regional leader regarding proven reserves, holding almost $80 \%$ of the entire region's proven reserves of natural gas (BP, 2019).

The OECD Pacific region is the last region in natural gas production and practically the entire region's output is represented by a single country - Australia. The world ranking of this region's gas production might change not too far into the future though, considering the recent rapid expansion of gas production in Australia. Additionally, Australia has the largest gas reserves in the region and is the world's second largest natural gas exporter, well on track to surpass Qatar for first place (URL16; URL17).

\subsection{Actual consumption up to 2018}

North America is the largest natural gas consuming region in the world and the U.S. represents almost $90 \%$ of the region's consumption as the world's leader, the rest being Canada. More than two thirds of the entire U.S. consumption came from electrical power generation and the industrial sector in 2018. Transportation accounted for only $3 \%$ of consumption, while the rest was 
consumed by residential and commercial sectors. Texas, California, Louisiana, Florida and Pennsylvania were the top five gas consuming states and accounted for over $37 \%$ of the total U.S. consumption (URL18).

The Middle East \& Africa are the second largest natural gas consuming region, with $18 \%$ percent of global natural gas consumption in 2018. Divided further into smaller regions, the Middle East accounted for $14 \%$ compared to Africa's 4\% share of the world's gas consumption. In 2012, natural gas accounted for almost half of the total Middle Eastern energy consumption, which was more than in any other region. The largest share of Middle Eastern gas consumption was accounted for by the industrial sector, followed by electric power generation. It is also this region where many countries are experiencing strains on domestic energy supplies due to the fast-growing energy demand stimulated by very low energy prices and the adoption of economic development models based on energy intensive industries (Cueille, 2012). In Africa, it is electric power generation that represents the largest share of the region's natural gas consumption, closely followed by the industrial sector. Africa's natural gas consumption has been steadily rising since 1980 and has more than doubled from 2000 to 2018. Such an increase in energy demand and thus natural gas consumption in Africa was and still is fuelled by rapid population growth, urbanization, economic development as well as rising living standards, human development and increased access to energy and electricity (URL24). One of the examples is the construction of the ROMPCO pipeline for gas transportation from Pande and Tamane natural gas fields in Mozambique to an existing gas pipeline in Secunda. This development resulted in gas consumption increasing by more than $100 \%$ in southern Africa, after gas flow through the ROMPCO pipeline commenced in 2004 (Africa50/EFI, 2018; URL9).

In 2018, Asia was the third largest gas consuming region, at $17 \%$ of global consumption. Broken down into smaller regions, China accounted for 7\%, East Asia another $7 \%$ and South Asia $3 \%$ of the world's natural gas consumption. Despite slower growth than expected, since 2015, the demand for natural gas has still increased significantly in China and East Asia. China's new leadership puts high importance on ecological and environmental protection that further grows in importance with rising concerns about pollution among the growing Chinese middle class. The effects of China's shift to cleaner sources of energy, in order to improve the quality of air, can be seen in its coal-to-gas and coal-to-electricity projects which, in 2017, included 12 cities, but were later expanded to encompass 35 cities (URL26). It is these and similar projects that keep China's natural gas demand growing rapidly and keeping China on course to becoming the world's largest LNG importer, after it has recently surpassed South Korea and reached second place. South Korea is another country which saw a sig- nificant rise in its natural gas demand after 2015. Furthermore, during his election campaign in 2017, President Moon Jae-in gave a promise to replace coal and nuclear power generation with natural gas and renewable energy. South Asia has also seen rapid expansion in gas demand. The largest share of gas demand in South Asia was accounted for by electrical power generation, although it experienced slower growth due to strong competition from other energy sources, such as coal and renewables. In Bangladesh, India and Pakistan, the main contributor to demand growth was the industrial sector, particularly for fertilizers to meet the needs of the growing population (URL20).

In the region of transition economies, the five largest natural gas consuming countries are Russia, Uzbekistan, Ukraine, Turkmenistan and Kazakhstan, though Russia alone consumes almost four times more gas than the next four countries combined. Russian natural gas consumption steadily grew from $366 \mathrm{bcm}$ in 2000 to 455 bcm in 2018 and increased by a little over $24 \%$ in 18 years. In the same year, natural gas accounted for $54 \%$ of all of Russia's primary energy consumption, up from $53 \%$ in 2017. Electric power generation and heat production use most of Russia's domestically consumed natural gas, more specifically, about half of all gas consumption in the country. Ukrainian natural gas consumption has been on a slight downward trend from 2000 until 2009, when consumption drastically fell, coinciding with the Russo Ukrainian gas pricing dispute. Consumption recovered a bit after that, but has been constantly falling since 2011. To put things into perspective, Ukraine's gas consumption in 2000 was at $74.20 \mathrm{bcm}$, and in 2018, it stood at $30.57 \mathrm{bcm}$, a decrease of close to $60 \%$. Ukrainian total energy output decreased by $16 \%$ in 2015 , mostly as a result of declining industrial output, which could perhaps be linked to the 2014 Crimean crisis. In 2015, natural gas was the second largest component of Ukraine's primary energy consumption, accounting for $30 \%$, right after coal, which represented $34 \%$ of consumption of the entire country's primary energy (Oxford IES, 2018; URL10).

OECD Europe is the fifth largest natural gas consuming region in the world, with the most significant consumers being Germany, the United Kingdom, Italy, Turkey and France. European gas consumption has remained about the same for the last 18 years with noticeable reductions in the years of 2009 and 2014, both coinciding with the Russo-Ukrainian crisis. Since 2014, European consumption has been growing again, fuelled by continued economic recovery and the increased use of natural gas in the sector of electrical power generation as lower gas prices, along with an increase in coal prices, allowed natural gas to more easily compete with coal in electrical power generation in some European countries. The top three consumers and France have, in line with the rest of Europe, had relatively minor changes. Among them, the UK is notable with a de- 
crease in its gas consumption of over $20 \%$ since the year 2000. Turkey however, in contrast to other countries on the list of major European consumers, has experienced major gains as its consumption grew by $240 \%$ from 2000 to 2018 (BP, 2019).

The sixth region in the world is the region of Latin America with its leading consumers being Mexico, Argentina, Brazil, Venezuela and Trinidad \& Tobago. The region's total consumption has about doubled over the past 18 years due to increasing investments and availability of domestic supplies, although recent growth was a little slower than in the first half of the relevant period (BP, 2019; URL22).

The Pacific region is the seventh region regarding natural gas consumption. Although overall gas consumption has grown by almost $60 \%$ from 2000 to 2018 , since 2014 , the demand in gas has been slightly decreasing. This was mostly due to a decrease in Japan's consumption, but Australian demand has been levelling off too over the past several years. Among the three countries in the region, Japan is a dominant consumer accounting for over $70 \%$ of the entire region's consumption. In 2011, after the nuclear shutdown due to the Fukushima accident, Japan's LNG demand increased by $30 \%$ despite a sharp increase in price, as it was LNG that compensated for the decline of nuclear power generation. As of 2018, Japan was the sixth country in the world regarding natural gas consumption as it was overtaken by Canada for fifth place in the same year. Natural gas accounted for almost a quarter of Japan's total primary consumption in 2015, while in the same year, 63\% of all gas in the country was consumed for electrical power generation (BP, 2019; URL11).

\subsection{Actual regional gas import dependence up to 2018}

Natural gas imports in the United States have been on a steady rise until the start of a downward trend in 2007 that has continued to this day. In contrast to imports, US gas exports have steadily grown, with an annual average growth of $14 \%$. In 2018 , the U.S. represented $10.2 \%$ of global natural gas exports, $70 \%$ of which was exported via pipelines and the rest was exported as LNG.

Natural gas imports in Europe have been increasing until 2009, when import oscillations started as a result of the economic recession and diplomatic tensions between Russia and Ukraine. The trend of oscillations continues to this day with a negative average annual import growth of $-0.1 \%$. In 2018, Europe remains the largest natural gas importer in the world, while its export share in the world stands at only $1.2 \%$ and all of it being exported as LNG. Since 2011, Russian gas imports have constantly fallen, while exports, an important part of the Russian economy have oscillated quite a bit, with an exception in 2009 when a significant drop is recorded as a result of the Russo-Ukrainian crisis. However, Russia still re- mains a natural gas export powerhouse with over $26 \%$ of global natural gas exports in 2018. Most Russian exports, almost 90\%, go to Germany, Italy, Turkey and Eastern Europe, while just above $10 \%$ is exported as LNG to the UK, France and Japan.

Middle Eastern gas exports have grown constantly until 2015, when the growth levelled off and exports have remained roughly the same since, which translates into an average annual growth of $7.2 \%$. In 2018, Middle East accounted for $14.2 \%$ of global exports, making it the second largest natural gas exporter in the world. Most of the Middle Eastern exported gas is in the form of LNG, a major part of it being Qatar's LNG exports to Asia, the Pacific region and Europe. While African gas imports are negligible, its exports are significant, as in 2018 , it accounted for almost $10 \%$ of global exports and was the fourth largest exporting region in the world. The majority of African gas exports are as LNG, mainly to Europe and Asia. The rest is exported via pipelines and almost exclusively to Europe. Strong growth of the Chinese economy is followed by a major increase in Chinese natural gas demand, as can be seen in the numbers. China has had the highest average annual demand growth of natural gas among all the regions in the last decade, a staggering 36\%. Such growth has resulted in China representing $12.9 \%$ of global imports in 2018, most of the imports being LNG. The largest supplier to China's LNG market is Australia, with over $40 \%$ of all Chinese LNG imports. Other major importing countries in the Asian region are South Korea, India and Taiwan, all of whom are some of the largest LNG importing countries in the world. In 2013, steady natural gas import growth was replaced by a slight annual decrease in OECD Asia, which in this paper would cover the Pacific region along with South Korea. The average annual import growth rate in OECD Asia over the last ten years stands at $2.5 \%$, while in 2018 , it accounted for $19 \%$ of global natural gas imports, most of those imports being in the form of LNG. This region is also home to the largest LNG importing country in the world, Japan. The most significant supplier of LNG to Japan is Australia, which supplies about 35\% of Japan's demand, followed by Malaysia, Qatar and Russia. Exports of OECD Asia have recorded constant growth and are almost exclusively Australian exports. OECD Asia's share of global natural gas exports in 2018 stood at 9.7\% (BP, 2019).

\subsection{Actual gas prices movements}

The average German import price has been designated here as a reference value for Europe, while price movements in the North American region were based on the U.S. Henry Hub natural gas price - a reference price for North America. Japan LNG is an average import LNG price in Japan, including average insurance and freight costs. Natural gas prices have sharply increased since 2000, and have remained such until 2014. 2014 sees a drastic reduction in gas prices, which remain rela- 
Table 2: Actual and projected gas production and share of global comparison by region

\begin{tabular}{|c|c|c|c|c|}
\hline Region & $\begin{array}{l}\text { Production } 2018(\mathrm{bcm}) \\
\text { (\% of global) }\end{array}$ & $\begin{array}{l}\text { Projected } 2020(\mathrm{bcm}) \\
\text { (\% of global) }\end{array}$ & Deviation (bcm) & $\begin{array}{l}\text { Relative deviation } \\
(\%)\end{array}$ \\
\hline Africa \& Middle East & $924(24)$ & $863(20)$ & 61 & 7 \\
\hline Latin America & $214(6)$ & $345(8)$ & -131 & -38 \\
\hline Asia & $502(13)$ & $604(14)$ & -102 & -17 \\
\hline Transition economies & $841(22)$ & $1208(28)$ & -368 & -30 \\
\hline Pacific & $130(3)$ & $86(2)$ & 44 & 51 \\
\hline Europe & $221(6)$ & $302(7)$ & -81 & -27 \\
\hline North America & $1017(26)$ & $906(21)$ & 110 & 12 \\
\hline World & 3868 & 4315 & -447 & -10 \\
\hline
\end{tabular}

tively low until 2018. A combination of abundant supply of LNG, low oil prices, the high availability of gas and decreased demand growth is keeping gas prices much below the 2011-2014 level. Gas prices seem to have bottomed out in the US, Europe and Japan and are expected to increase further in future (URL1).

\section{Comparison of actual and projected global natural gas movements}

The primary purpose of this paper is to compare the projected and actual natural gas market movements, which is what shall be done in this section. Of course, the comparison is not ideal due to the two-year gap between data sets, however it can still serve as a means of viewing actual market trends as opposed to projected ones. As previously mentioned, all comparisons are based on data from basic reports (BP, 2019; IEA, 2000).

\subsection{Comparison of predicted and actual production}

The total world natural gas production predictions for 2020 look promising. In 2018, global natural gas production was $10 \%$ lower than the predicted volumes for 2020 , but with another two years of stable growth which picked up additional pace in 2016, it is likely that the World Energy Outlook 2000 projections will be almost perfect. Predictions by region, however, mostly have a smaller chance of being realized. North American production in 2018, carried by the "American shale revolution," has already been $12 \%$ higher than 2020 predictions. European production is almost $30 \%$ lower than predictions and with only two years until 2020, combined with the downward production trends, the likelihood of European production meeting the 2020 predictions is practically zero. Weak European production relative to projections is probably the result of the unforeseen, already mentioned decreases in production in British gas fields, as well as Groningen Field in the Netherlands, in which production has been capped due to seismic activity linked to gas production. Lesser than expected investments in Norwegian fossil fuel industry and by extension natural gas, have likely also influenced the large gap between the realized and predicted European production. In relation to predictions, Latin America has also underperformed as its production should increase by $61 \%$ in two years in order to meet the 2020 projections. Such expectations are of course, unrealistic, especially when taking into account the fact that Latin American production has essentially stagnated in the last decade. The regions of transition economies have also performed below expectations. Looking at the numbers at the beginning and the end of the observed period, an increase in production is clear. However, production growth was unstable and well below the World Energy Outlook 2000 projections, mostly due to geopolitical reasons. Along with North America, one more region already surpassed the 2020 projections in 2018. It is the combined region of Africa and Middle East whose production growth was mostly fuelled by increasing domestic natural gas consumption. This region realized a 7\% higher production in 2018 than the projected 2020 production volume and in case of continued recorded growth for the next two years, the difference between the realized production and projections will only ever increase. The largest relative deviation is in the Pacific region, where the only significant natural gas producer is Australia surpassed the 2020 projections in 2018 by more than $50 \%$, owing to an increase in production since 2015. Among all regions, Asia has the highest chance of meeting projected natural gas production. Asian production in 2018 was $17 \%$ lower than 2020 projections. However, with recent growth continuing for the next two years, Asian production should be within a few percent of the predicted 2020 production volumes. Table 2 shows actual and projected gas production and a share of global comparison by region.

Deviation between the realized and projected production will inevitably lead to deviation between the real and predicted regional shares in global natural gas production. In 2018, Africa and the Middle East, the Pacific region and North America occupied larger global production shares than expected, mostly at the expense of transition economies and it is probable that their shares will grow even further over the next two years due to 
Table 3: Actual and projected gas consumption and share of global comparison by region

\begin{tabular}{|l|l|l|l|l|}
\hline Region & $\begin{array}{l}\text { Consumption 2018 } \\
\text { (bcm) (\% of global) }\end{array}$ & $\begin{array}{l}\text { Projected 2020 (bcm) } \\
\text { (\% of global) }\end{array}$ & Deviation (bcm) & $\begin{array}{l}\text { Relative deviation } \\
\text { (\%) }\end{array}$ \\
\hline North America & $933(24)$ & $905(22)$ & 28 & 3 \\
\hline Europe & $482(13)$ & $756(18)$ & -274 & -36 \\
\hline Transition economies & $613(16)$ & $830(20)$ & -218 & -26 \\
\hline Pacific & $161(4)$ & $141(3)$ & 21 & 15 \\
\hline Latin America & $258(7)$ & $364(9)$ & -106 & -29 \\
\hline Asia & $664(17)$ & $651(16)$ & 13 & 2 \\
\hline Africa & $150(4)$ & $126(3)$ & 24 & 19 \\
\hline Middle East & $553(14)$ & $357(9)$ & 196 & 55 \\
\hline World & 3849 & 4130 & -281 & -7 \\
\hline
\end{tabular}

rapid production growth. In spite of that, transition economies could take back at least a part of their share over the next two years owing to the upswing in production since 2016. In 2018, Europe and Latin America already represented a smaller global production share than predicted for 2020. Accounting for their negative growth rates and stagnation, respectively, over the last decade, the only realistic expectation is further shrinkage of their global production shares over the next two years. Asia is once again the region whose realized market movements most accurately match predictions. Considering the current share of $13 \%$ and assuming the continued trends for the next two years, it is relatively safe to expect that Asia will represent the projected $14 \%$ of world natural gas production in 2020 .

\subsection{Comparison of predicted and actual consumption}

Natural gas demand in 2018 totalled $3849 \mathrm{bcm}$ and was only $7 \%$ lower than 2020 projections of $4130 \mathrm{bcm}$, thus it is likely that predicted and realised consumption will be nearly identical in 2020. Among regions, the Middle East stands with a relative deviation of more than 50\%. In WEO 2000 predictions, China was considered to be the most significant and important driver natural gas consumption growth in Asia and China exceeded even these, already high expectations, but East Asia and South Asia were below expected consumption. Thus, natural gas consumption in 2018 in Asia was very close to the projected consumption in 2020 . The remaining regions which had already achieved greater consumption than predicted by 2018 are North America, the Pacific region and Africa. Considering the trends of constant growth in North America and Africa, deviations will inevitably increase. In recent years, the Pacific region has recorded a weak downward trend regarding consumption, which could bring it closer to meeting the 2020 projections in the following two years. In 2018, all other regions had recorded consumption which was nowhere near the 2020 predictions and it was unrealistic to expect any of them to meet the predictions by the end of the observed period. Table 3 shows actual and projected gas consumption and share of global comparison by region.

Again, as was the case in production, deviations between the realized and projected regional consumption will result in deviations between the predicted and realized regional shares in global consumption. The largest positive difference between the realized and predicted shares is in the Middle East and North America, which represents a large part of global natural gas consumption. Owing to rapid consumption growth in the Middle East and North America, Europe's global consumption share with its stagnating consumption, will drop further in the next two years and thus increase the deviation in 2020 even more. Transition economies have experienced faster growth in their consumption since 2017, which could help them to partly bridge the gap between the predicted and realized share in global consumption by 2020. In 2018, Asia was marginally over 2020 projections while practically stagnating Latin American consumption will cause shrinkage in that region if no changes occur and the difference between real and predicted share will inescapably increase. Until 2018, the Pacific region had achieved a larger share than predicted in global gas consumption. However, due to recent downward consumption trends, its consumption could very well drop to the projected value by 2020 . Lastly remains Africa, which as of 2018 slightly surpassed the 2020 projections and will, if its growth remains uninterrupted for the next two years, certainly increase the difference.

\subsection{Comparison of predicted and actual regional gas import dependence}

Europe is not as dependent on natural gas imports as was predicted and gas imports required to supplement consumption are a great deal lower than projected. In order to meet the predicted import volume, Europe would have to almost double its imports in the next two years. This, of course, is not a realistic expectation considering recent production/consumption movements in Europe. Instead of becoming an importer of natural gas as predicted, North America has developed into a sig- 
Table 4: Gas import dependence comparison by region, negative values indicate exports

\begin{tabular}{|l|l|l|l|l|l|}
\hline & \multicolumn{2}{|l}{ Imported gas volumes (bcm) } & \multicolumn{2}{l|}{$\begin{array}{l}\text { Shares of imported gas in domestic } \\
\text { consumption (\%) }\end{array}$} \\
\hline Region & Actual 2018* & Projected 2020* & Deviation** & Actual 2018* & Projected 2020.* $^{*}$ \\
\hline Africa \& Middle East & -221 & -357 & -136 & -31 & -74 \\
\hline Latin America & 44 & 15 & 29 & 17 & 4 \\
\hline Asia & 162 & 65 & 97 & 24 & 10 \\
\hline Transition economies & -228 & -299 & -71 & -37 & -36 \\
\hline Pacific & 31 & 53 & -22 & 19 & 38 \\
\hline Europe & 261 & 469 & -208 & 54 & 62 \\
\hline North America & -84 & 54 & -138 & -9 & 6 \\
\hline
\end{tabular}

*minus represents export of natural gas

**minus can represent smaller imports or larger exports than projected

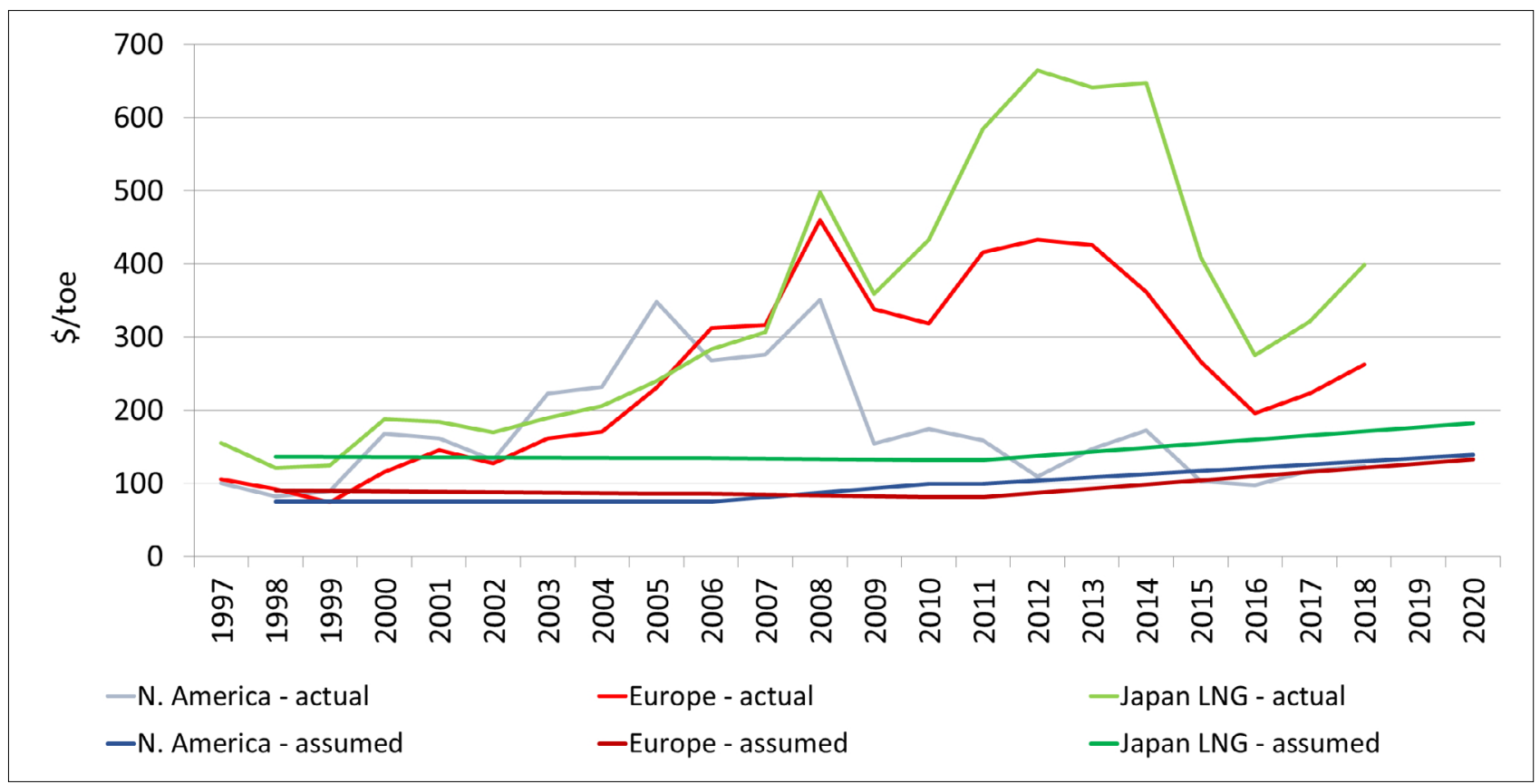

Figure 1: Comparison of actual and assumed prices movements in selected regions

nificant exporter despite a greater than predicted consumption. North America has become unexpectedly energy independent when it comes to natural gas, with rising exports because of the shale revolution. Gas import independence of the transition economies was almost perfectly predicted as a ratio of exports to domestic consumption, where the exported share in 2018 was almost identical to the one predicted for 2020. On the other hand, the total volume of exports was significantly lower than predicted, which is the result of the large difference between the predicted and actual production volumes. Asian 2018 imports were more than twice the projected imports in 2020, referring to the share of imported gas in domestic consumption as well as the total imported volume. By the end of the observed period, the difference will only increase, considering the gas demand growth in that region. In the region of Africa and the Middle East, export is significantly lower than predicted, as the total volume as well as the ratio of exports to domestic consumption. The cause of this is the significantly higher domestic consumption in the Middle East and the somewhat higher domestic consumption in Africa compared to the predictions. The combined region of Africa and the Middle East has been steadily increasing its export volumes since 2016, which will help to bridge the gap between the realized and projected volumes by the end of the observed period if the trend continues. Table 4 shows gas import dependence comparison by region.

\subsection{Comparison of assumed and actual prices movements}

Although prices were not predicted but assumed in WEO 2000, a comparison between real and assumed price movements is undoubtedly valuable, considering the fact that prices are one of the most important factors 
in predicting market movements. Figure 1 shows large deviations of historical price movements from the assumed trends, in the three main regions, which have undoubtedly significantly contributed to deviations between the realized and predicted volumes of production, consumption and import dependence.

\section{Conclusions}

Predictions of market movements 20 years into the future are very useful, but they do have certain limitations. Those limitations especially apply to goods whose prices are regional and linked to price movements of another good, as is the case with natural gas. The shortcomings of long-term predictions stem from the way they are created in the mathematical model as well as the susceptibility of the energy market, especially oil and natural gas as strategic fuels, to external influences. Some fundamental factors of the mathematical model are price movements and technological development which are used to predict consumption. Those predictions, among other factors, are then used to predict production and finally, both of the previous predictions are used in import dependence predictions. External influences, such as geopolitics, trade disputes and sanctions, along with wars, terrorism and seismic activity can directly and decisively affect production. Internal state policies, competing energy sources, disasters such as Fukushima, environmental awareness of the population and activism directly impact consumption and its production, which in turn changes regional imports and exports. It is rather clear that changes in one of the fundamental factors entail and magnify the error of further predictions. This is particularly noticeable in the forecasts for factors including consumption. Besides, natural gas production will always tend to meet consumption such that in the case of reduced production in one region, production will be increased in another region to meet the demand, and thus drastic changes will occur in the regional import and export balance.

As previously stated, the goal of this paper was to compare the projected and actual natural gas market indicators since an accurate prediction of energy indicators is critical for orientation in the energy market, and it could give direction for policymakers and market participants. A projection of future trends is not made in this paper, as this would require a different approach, and a large amount of data is required to make this projection. Also, due to the Covid-19 pandemic, which can be characterized as an unpredictable event, the projection is extremely difficult to make. The analysis showed that in the case of predicted world natural gas production, WEO 2000 projections were very accurate, however, regional production prediction has not shown the same matching, with significant relative deviation especially for the Pacific region with more than $50 \%$. Asia was the region with market movements that were the most accurately matched with predictions. The same pattern was observed when the predicted and actual consumption were compared. Natural gas demand is expected to closely match 2020 predictions. Regional consumption also showed significant deviation, especially in the case of the Middle East with more than $50 \%$ relative deviation among the regions. Opposite of the production and consumption trends, analysed gas import dependence has shown mismatching of imported and predicted volumes, especially for Europe and North America. Trends for Europe have shown almost double quantities imported than previously predicted, and a total mistake for North America import dependence, since the shale revolution has not been calculated into predictions, and it helped the USA to become a net exporter instead of being a gas importer. Gas import independence of the transition economies has shown a perfect match with predictions, but export volumes have not been so successfully predicted. Analyses of assumed trends and real prices have shown the largest deviations of all the analysed indicators. The novelty of this paper is contained in the results of the comparative analysis of predicted and actual market indicators. Based on the results, it could be emphasized that for strategical planning and policy-making purposes, the predictions of natural gas production, consumption, or even import independence could be considered with great certainty, while price assumptions in the case of natural gas have shown significant mismatching, therefore, should be very carefully perceived. The authors suggest that for the final research confirmation, the same analysis should be conducted after the 2020 data set will be available.

\section{References}

\section{Papers}

Akdag S. and Yıldırım H. (2020): Toward a sustainable mitigation approach of energy efficiency to greenhouse gas emissions in the European countries. Heliyon, 6, 3, e03396. https://doi.org/10.1016/j.heliyon.2020.e03396

al Irsyad M.I., Halog A. and Nepal R. (2019): Renewable energy projections for climate change mitigation: An analysis of uncertainty and errors. Renewable Energy, 130, 536546. https://doi.org/10.1016/j.renene.2018.06.082

Bayer P. and Aklin M. (2020): The European Union emissions trading system reduced $\mathrm{CO} 2$ emissions despite low prices. Proceedings of the National Academy of Sciences, 117, 16, 8804-8812. https://doi.org/10.1073/pnas.1918128117

Gürsan C. and de Gooyert, V. (2021): The systemic impact of a transition fuel: Does natural gas help or hinder the energy transition?, Renewable and Sustainable Energy Reviews, 138, 110552. https://doi.org/10.1016/j.rser.2020.110552

Ikpeka P.M., Amaechi U.C., Xianlin M. and Ugwu J.O. (2019).: Application of machine learning models in predicting initial gas production rate from tight gas reservoirs. Rudarsko-geološko-naftni zbornik (The Mining-Geological-Petroleum Bulletin), 34,3, 29-40. https://oi. org/10.17794/rgn.2019.3.4 
Kaufmann R.K. and Connelly C. (2020): Oil price regimes and their role in price diversions from market fundamentals. Nat. Energy, 5, 2, 141-149. https://doi.org/10.1038/ s41560-020-0549-1

Lu H., Ma X., Ma M. and Zhu S. (2021): Energy price prediction using data-driven models: A decade review. Computer Science Review, 39, 100356. https://doi.org/10.1016/j.cosrev.2020.100356

Nowotarski J. and Weron R. (2018): Recent advances in electricity price forecasting: A review of probabilistic forecasting. Renewable and Sustainable Energy Reviews, 81, 1548-1568. https://doi.org/10.1016/j.rser.2017.05.234

Paraschiv S. and Paraschiv L.S. (2020): Trends of carbon dioxide (CO2) emissions from fossil fuels combustion (coal, gas and oil) in the EU member states from 1960 to 2018 . Energy Reports, 6, 8, 237-242. https://doi.org/10.1016/j. egyr.2020.11.116

Scharf H., Arnold F. and Lencz, D. (2021): Future natural gas consumption in the context of decarbonization - A metaanalysis of scenarios modeling the German energy system. Energy Strategy Reviews, 33, 100591. https://doi.org/ 10.1016/j.esr.2020.100591

Smajla I., Crneković R., Karasalihović Sedlar D. and Božić F. (2020): Potential of Croatian liquefied natural gas (LNG) terminal in supplying regional natural gas markets. Rudarsko-geološko-naftni zbornik (The Mining-Geological-Petroleum Bulletin), 35, 4, 93-101. https://doi.org/ 10.17794/rgn.2020.4.8

Strpić K., Miličević M. and Kurevija T. (2017): Development of Tight Oil Resources in USA: Profitability of Exploitation and Effect of Macroeconomic Indicators in Volatile Oil Price Environment. Rudarsko-geološko-naftni zbornik (The Mining-Geological-Petroleum Bulletin), 32, 3, 2333. https://doi.org/10.17794/rgn.2017.3.3

\section{Reports (publicly available):}

AfricaA50/Energy Futures Initiative (2018): Investing in Natural Gas for Africans: Doing Good and Doing Well., https://www.africa50.com/fileadmin/uploads/africa50/Photos/Knowledge_Center/Investing_in_Natural_Gas_for_ Africans_-_Doing_Good_and_Doing_Well.pdf (accessed 19.8.2019.)

BP - British petroleum Petroleum (2019): Statistical Review of World Energy 2019., https:/www.bp.com/content/dam/ $\mathrm{bp} /$ business-sites/en/global/corporate/pdfs/energy-econo$\mathrm{mics} /$ statistical-review/bp-stats-review-2019-full-report. pdf (accessed 5.8.2019)

Cueille, J. P. (2012): The oil and gas producing countries of North Africa and the Middle East. IFP Energies Nouvelles Panorama 2012.,http://www.arabdevelopmentportal.com/ sites/default/files/publication/275.the_oil_and_gas_producing_countries_of_north_africa_and_the_middle_east. pdf (accessed 14.8.2019)

IEA - International Energy Agency (2000): World Energy Outlook 2000., https://www.iea.org/media/weowebsite/20081994/weo2000.pdf (accessed11.08.2019.)

NEB - National Energy Board (2017) Canada's Role in the Global LNG Market Energy Market Assessment., https:// www.cer-rec.gc.ca/nrg/sttstc/ntrlgs/rprt/2017lngmrkt/ 2017lngmrkt-eng.pdf (accessed 12.3.2020.)

Oxford Institute for Energy Studies (2018): The Development of Natural Gas Demand in the Russian Electricity and Heat Sectors., https://www.oxfordenergy.org/wpcms/wp-content/uploads/2018/08/The-Development-of-Natural-GasDemand-in-the-Russian-Electricity-and-Heat-SectorNG-136.pdf (accessed 24.3.2020.)

Wynn, G., Coghe, P. (2017): Europe's Coal-Fired Power Plant: Rough Times Ahead. Institute for Energy Economics and Financial Analysis, Report published on May 2017. https://www.cire.pl/pliki/1/2017/europe_coal_fired_plants rough_times_ahead_may_2017.pdf (accessed24.3.2020.)

\section{Internet sources:}

URL1: Atradius (2017): Natural gas prices have reached a turning point. URL:https:/group.atradius.com/publications/gas-price-update-2017.html (accessed 20.3.2020.)

URL2: Atradius (2018): European gas market outlook. URL:https://group.atradius.com/publications/economicresearch/european-gas-market-outlook-2018.html\# (accessed 15.3.2020.)

URL3: Besta, S. (2019): What are the largest natural gas fields in Russia? NS Energy. URL:https://www.nsenergybusiness.com/features/largest-natural-gas-fields-in-russia/ (accessed 23.3.2020)

URL4: CER - Canada Energy Regulator (2016): Canadian Energy Dynamics: Highlights of 2015 - Energy Market Analysis.URL:https://www.cer-rec.gc.ca/nrg/ntgrtd/mrkt/ dnmc/2015/index-eng.html (accessed 11.3.2020.)

URL5: CER - Canada Energy Regulator(2020): Provincial and Territorial Energy Profiles - Canada. URL: https:// www.cer-rec.gc.ca/nrg/ntgrtd/mrkt/nrgsstmprfls/cda-eng. html (accessed 11.3.2020.)

URL6: Clemente, J. (2016): Norway's Natural Gas Problems Help U.S. LNG in Europe. Forbes. URL:https://www. forbes.com/sites/judeclemente/2016/03/02/norways-natural-gas-problems-help-u-s-lng-in-europe/\#2da2ace81bcf (accessed 16.4.2020.)

URL7: EB - Encyclopædia Britannica (2020): Location of major gas fields. URL:https://www.britannica.com/science/natural-gas/Location-of-major-gas-fields (accessed 12.3.2020.)

URL8: EIA - U.S. Energy Information Administration (2012): Top 5 producing states' combined marketed natural gas output rose in 2011. URL: https://www.eia.gov/todayinenergy/detail.php?id=6030 (accessed 10.3.2020.)

URL9: EIA - U.S. Energy Information Administration (2016): International Energy Outlook 2016.URL: https://www.eia. gov/outlooks/ieo/pdf/nat_gas.pdf (accessed 10.3.2020.)

URL10: EIA - U.S. Energy Information Administration (2017): Ukraine. URL:https://www.eia.gov/international/ analysis/country/UKR (accessed 14.4.2020.)

URL11: EIA - U.S. Energy Information Administration (2017): Japan. URL: https://www.eia.gov/international/ analysis/country/JPN (accessed 15.3.2020.)

URL12: EIA - U.S. Energy Information Administration (2019): U.S. natural gas production hit a new record high 
in 2018. URL: https://www.eia.gov/todayinenergy/detail. php?id=38692 (accessed 21. 4. 2020.)

URL13: EIA - U.S. Energy Information Administration (2019b): Canada - Executive summary.URL: https://www. eia.gov/international/analysis/country/CAN (accessed 21.4.2020.)

URL14: EIA - U.S. Energy Information Administration (2019c): Which states consume and produce the most natural gas? URL: https://www.eia.gov/tools/faqs/faq.php?id $=46 \& \mathrm{t}=8$ (accessed 21.4.2020.)

URL15: EIA - U.S. Energy Information Administration (2019): Iran - Executive summary. URL: https:/www.eia.gov/international/analysis/country/IRN (accessed 28.3.2020.)

URL16: EIA - U.S. Energy Information Administration (2019): China adds incentives for domestic natural gas production as imports increase. URL: https://www.eia.gov /todayinenergy/detail.php?id=41773 (accessed 1.4.2020.)

URL17: EIA - U.S. Energy Information Administration, (2019f): Australia is on track to become world's largest LNG exporter. URL: https://www.eia.gov/todayinenergy/ detail.php?id=40853 (accessed 1.4.2020.)

URL18: EIA - U.S. Energy Information Administration (2019g): Natural gas explained - Use of natural gas. URL: https://www.eia.gov/energyexplained/natural-gas/use-ofnatural-gas.php (accessed 31.3.2020.)

URL19: EIA - U.S. Energy Information Administration (2020): Natural gas explained - Where our natural gas comes from.URL:https://www.eia.gov/energyexplained/ natural-gas/where-our-natural-gas-comes-from.php (accessed 31.3.2020.)

URL20: HSNW - Hellenic Shipping News Worldwide (2019): The oil and gas market in Asia is heating up. URL:https:// www.hellenicshippingnews.com/the-oil-and-gas-marketin-asia-is-heating-up/ (accessed 17.4.2020.)

URL21: IEM - Iran's Energy Ministry (2009): Iran Oil Ministry Annual Bulletin, 5th Edition. URL: https://en.wikipe-
dia.org/wiki/Natural_gas_reserves_in_Iran\#cite_note-11 (accessed 29.3.2020.)

URL22: IOGP - International Association of Oil\& Gas Producers (2018): Oil \& gas production in Central \& South America: Investment needed to meet rising regional demand. URL:https:/www.iogp.org/bookstore/product/global-energy-brief-latin-america/ (accessed 30.4.2020.)

URL23: OT - Offshore Technology (2019): Top ten offshore oil and gas fields in Europe. URL:https://www.offshoretechnology.com/features/top-ten-offshore-oil-and-gasfields-in-europe/ (accessed 13.3.2020.)

URL24: Putter, A. (2018): Natural Gas in Southern Africa, Part 1: Current supply and demand. Owner Team Consultation. URL:https://www.ownerteamconsult.com/naturalgas-in-southern-africa-part-1/ (accessed 14.4.2020)

URL25: Razlomalin, I., Sushin, I., Waterlander, W. (2018): The road to China: An opportunity for Russian gas to play out. McKinsey \& Company. URL:https://www.mckinsey. com/industries/oil-and-gas/our-insights/the-road-to-chinaan-opportunity-for-russian-gas-to-play-out (accessed 17. 3.2020)

URL26: TME - The Maritime Executive (2019): IEA: 2018 was Another Golden Year for Natural Gas. URL:https: //www.maritime-executive.com/article/iea-2018-was-another-golden-year-for-natural-gas (accessed 19.4.2020.)

URL27: Verdonck, R. and Van Der Sarre, M. (2016): Europe's biggest natural gas producer is running out of fuel. Bloomberg Professional Services. URL:https://www.bloomberg. $\mathrm{com} /$ professional/blog/europes-biggest-natural-gas-producer-running-fuel/ (accessed 14.3.2020.)

URL28: World Oil (2020): U.S. crude oil and natural gas production increased in 2018, with $10 \%$ fewer wells. URL:https://www.worldoil.com/news/2020/2/3/us-crudeoil-and-natural-gas-production-increased-in-2018-with10-fewer-wells (accessed 11.3.2020.) 


\section{SAŽETAK}

\section{Analiza globalnih kretanja na tržištu prirodnoga plina}

Točno predviđanje energetskih pokazatelja presudno je za određivanje smjera energetskih politika tržišnih sudionika. Ovaj rad predstavlja komparativnu analizu prethodnih predviđanja i stvarnih globalnih kretanja u sektoru prirodnoga plina u nekoliko segmenata, odnosno u proizvodnji, potrošnji i regionalnoj ovisnosti o uvozu, kao i u prognoziranim i stvarnim kretanjima cijena. Cilj istraživanja bila je analiza podudaranja predviđenih i ostvarenih kretanja tržišnih pokazatelja. Projekcije su dobivene iz predviđanja predstavljenih u referentnome scenariju World Energy Outlook 2000 (WEO) Međunarodne energetske agencije (IEA), a obuhvaćaju razdoblje od 1997. do 2020. Referentni scenarij ne uzima u obzir politike koje su trebale biti provedene do 2020. godine. Stvarna kretanja prirodnoga plina na globalnome tržištu (proizvodnja, potrošnja, regionalna ovisnost o uvozu i cijene) temelje se na podatcima koje je objavio British Petroleum (podatci dostupni do 2018. godine) i odvojeni su u iste četiri kategorije kao i u predviđanju IEA-e. Predviđanja kretanja na tržištu 20 godina u budućnosti vrlo su korisna, ali imaju određena ograničenja. Ta se ograničenja posebno odnose na robu i dobra čija je cijena regionalna i povezana je s kretanjem cijena drugoga dobra, kao što je slučaj s prirodnim plinom. Vanjski utjecaji izravno utječu na proizvodnju i potrošnju i prilično je jasno da promjene u jednome od temeljnih čimbenika povlače i povećavaju pogrešku daljnjih predviđanja. Unatoč tome, predviđanja globalne proizvodnje i potrošnje pokazala su se vrlo preciznima. Na temelju rezultata istraživanja moguće je zaključiti da bi se za potrebe strateškoga planiranja i kreiranja politika s velikom sigurnošću mogla uzeti u obzir predviđanja proizvodnje, potrošnje, pa čak i ovisnosti o uvozu prirodnoga plina, dok su pretpostavljena kretanja cijena u slučaju prirodnoga plina pokazala znatna odstupanja od realnih cijena te treba biti pažljiv prilikom njihova sagledavanja.

\section{Ključne riječi:}

proizvodnja prirodnoga plina, potrošnja prirodnoga plina, predviđanje kretanja na tržištu plina, trendovi na energetskim tržištima

\section{Author's contribution}

Domagoj Šamarinec (1) (univ.bacc.ing.petrol, student) researched and collected data regarding production, consumption, prices and gas dependence, participated in writing all versions of the paper, collected data on IEA projections and visualized figures and tables. Daria Karasalihović Sedlar (2) (PhD full professor) devised the concept of the paper, participated in the writing of several chapters, researched multiple sources of literature and made some conclusions of the paper. Ivan Smajla (3) (mag. ing. petrol, teaching assistant, doctoral study) participated in the conceptualization of the work, participated in writing chapters and edited the paper. Lucija Jukić (4) (mag. ing. petrol, teaching assistant, doctoral study) proofread the paper, edited the paper, participated in the writing of certain chapters and made some conclusions of the paper. 